This item was submitted to Loughborough's Research Repository by the author.

Items in Figshare are protected by copyright, with all rights reserved, unless otherwise indicated.

\title{
Manufacturing individual opinions: market research focus groups and the discursive psychology of evaluation
}

PLEASE CITE THE PUBLISHED VERSION

http://dx.doi.org/10.1348/014466602760344250

PUBLISHER

Wiley (@ British Sociological Society)

VERSION

AM (Accepted Manuscript)

LICENCE

CC BY-NC-ND 4.0

\section{REPOSITORY RECORD}

Puchta, Claudia, and Jonathan Potter. 2019. "Manufacturing Individual Opinions: Market Research Focus Groups and the Discursive Psychology of Evaluation”. figshare. https://hdl.handle.net/2134/15082. 
This item was submitted to Loughborough's Institutional Repository (https://dspace.lboro.ac.uk/) by the author and is made available under the following Creative Commons Licence conditions.

\section{creative
commons}

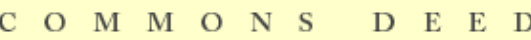

Attribution-NonCommercial-NoDerivs 2.5

You are free:

- to copy, distribute, display, and perform the work

Under the following conditions:

Attribution. You must attribute the work in the manner specified b the author or licensor.

Noncommercial. You may not use this work for commercial purposes.

No Derivative Works. You may not alter, transform, or build upon this work.

- For any reuse or distribution, you must make clear to others the license terms of this work.

- Any of these conditions can be waived if you get permission from the copyright holder.

Your fair use and other rights are in no way affected by the above.

This is a human-readable summary of the Leqal Code (the full license).

\section{Disclaimer 만}

For the full text of this licence, please go to: http://creativecommons.org/licenses/by-nc-nd/2.5/ 


\section{MANUFACTURING INDIVIDUAL OPINIONS:}

Market Research Focus Groups and the Discursive Psychology of Evaluation

Claudia Puchta \& Jonathan Potter

Discourse \& Rhetoric Group

Department of Social Sciences

Loughborough University

Loughborough

Leics

LE11 3TU

Published as:

Puchta, C. \& Potter, J. (2002). Manufacturing individual opinions: Market research focus groups and the discursive psychology of attitudes, British Journal of Social Psychology, 41, 345-363.

We would like to thank sue Condor and Steve Reicher for

detailed comments on an earlier version of this paper. The attitudes expressed in this draft are, of course, our own. 


\section{Abstract}

This paper addresses a paradox. On the one hand, discourse and rhetorical studies have provided evidence that evaluative talk is both variable and rhetorically organized. On the other, a wide range of social psychological research is produced that both presupposes and finds evidence of enduring underlying attitudes. One explanation for this may be that, on some occasions at least, the results of attitude research are a consequence of procedures that restrict and refine from everyday evaluative practices in a way that ensures the 'discovery' of underlying attitudes. This paper explores this explanation in one domain where there is a major practical concern with attitudes and opinions, namely market research focus groups. Detailed analysis of transcripts of 8 market research focus groups identifies three procedures that moderators use to produce freestanding opinion packages: (a) they display rhetorically embedded evaluations as inconsequential; (b) they provide formal guidance for participants to produce freestanding opinions; (c) they formulate participants' talk as freestanding opinions, stripping off rhetorical elements. The findings are supported by considering deviant cases. This illustrates one way in which evaluations are transformed into freestanding attitudes. More broadly contributes to a body of work that studies how social science methods work in practice. 


\section{Introduction}

Over the last decade a discursive social psychological approach has been developed in parallel to more established social psychological perspectives. Discursive social psychology (henceforth DSP) is the application of ideas from discourse analysis to issues in social psychology. Its publication record stretches back through the $80 \mathrm{~s}$ where empirical, theoretical and conceptual arguments were developed in both discourse and rhetoric research (e.g. Billig, 1985; Billig, 1996 [1987]; Litton and Potter, 1985; Potter and Wetherell, 1987). Since then these strands of work have largely merged together, drawing on work in conversation analysis (Atkinson and Heritage, 1984; Sacks, 1992), and tackling topics in both social and cognitive psychology (Antaki, 1994; Edwards, 1991, 1997; Edwards and Potter, 1992, 1993; Potter \& Edwards, forthcoming; Wetherell and Potter, 1992) .

In this paper we will push this argument forward using the topic of attitudes and opinions. This is a topic that has marked out DSP from social cognition and other traditional approaches. DSP has provided both a critique of tradition conceptualizations of attitudes (Billig, 1996 [1987], 1988, 1989; Burningham, 1995; Potter and Wetherell, 1987, 1988; Wetherell and Potter, 1992; Wetherell, et al., 1987) and a 
respecification in terms of evaluative practices and orientations (Potter, 1998; Myers, 1998; Verkuyten, 1998). Put simply, DSP studies documenting both the variation and rhetorical organization of evaluations present problems for social cognition and other traditional accounts of attitudes; while studies of the pragmatics of evaluations suggest new ways of understanding their role in people's practices.

Such DSP studies, however, throw up a paradox. How can they be reconciled with the wide range of research that both presupposes and finds evidence of enduring underlying attitudes? After all, attitudes continue to figure in a very large number of social psychological studies and continue to be viewed as one of its most indispensable concepts (Manstead, 1995). One possible way of making sense of this paradox is to consider the connection of method and theory. Could the sorts of methods of attitude research that have been used restrict the appearance of evaluative variation and exclude evidence of the rhetorical organization of evaluations? Arguments of this kind have been made with respect to Likert scales and other quantitative measurement techniques (Billig, et al., 1988; Potter, 1998; Potter and Wetherell, 1987).

In this study we consider an area of psychological research where qualitative studies of attitudes are commonplace, namely market research. In particular, we will consider the use of focus groups that are now widely used as a 
way of 'eliciting' people's opinions, attitudes and beliefs about products, policies and services. Our interest will be in the way evaluations are treated, and particularly how they are produced as 'freestanding opinion packages'. That is, how they are treated as bundled packets that can be listed, counted, and passed from one to another.

Focus groups are structured around an interactional dilemma (Puchta, 1999; Puchta and Potter, 1999; cf. Billig et al., 1988). On the one hand, focus group participants are asked to 'always say, =whatever comes to mind' (see extract above). On the other, participants seem to be carefully policed into 'what exactly comes to mind'. In this study we will investigate the procedures that focus group moderators use for discovering the traditional notion of opinion within participants, while overtly eliciting it from them.

\section{The Discursive Psychology of Evaluation}

In traditional social psychology attitudes are treated as having a number of core features. They are:
(a) located within the individual (and are perceptible as subjective experiences);
(b) these internal states can be observed in verbal, behavioural or physiological reactions;
(c) they are (generally) static; 
(d) individuals differ regarding their evaluative reactions; and

(e) these reactions can be measured by attitude scales.

Let us be cautious in what we are claiming. There is now a wide range of more or less subtle and complex theorizations of attitudes in the social cognition literature (see, for example, studies discussed in Eagly and Chaiken, 1993). Elsewhere we have discussed some of these theoretical complications (e.g. Potter, 1998). However, our concern in this paper is with the broad sweep of social psychological research, including research done in marketing contexts, that uses attitude measures without necessarily being concerned with potential theoretical nuances and respecifications. We take it that most readers will recognise the core features listed above as characteristic of studies that apply attitude notions to particular topics.

This traditional notion has been reworked from a discourse and rhetorical perspective. The rhetorical nature of attitudes is stressed by Billig (1988, 1989, 1991, 1992) who claims that, rather than carry attitudes around as fixed entities, people:

- give views in particular contexts;

- produce evaluations where there is at least the possibility of argument (they tend not to argue about the virtues of gravitational force); 
- while expressing an evaluation for something, and marking the justification of their own position, often simultaneously express criticisms against the counterposition.

Whereas Billig stresses that attitudes are rhetorically occasioned and are therefore inextricable from the arguments in which they occur, Potter \& Wetherell (1987; Potter, 1998) have drawn attention to what people are doing by making evaluations (or displaying a lack of evaluation) in particular settings. Both Billig and Potter \& Wetherell highlight variations in evaluations as evidence critical of traditional research. The point is here that evaluations are not treated as ready-made cognitive objects, but as entities that are worked up by the participants in ways that are suitable for what is being done (compliments and complaints, persuading people against courses of action, and so on).

In this paper our interest will be in whether the conduct of focus groups will involve particular interactional practices to strip off these rhetorical and performative elements of evaluative talk. That is, we will ask whether focus group practices obscure precisely those features of evaluations that distinguish DSP and traditional approaches.

Before moving to this, however, there are some terminological issues that need to be tackled to prevent confusion. Social psychologists have sometimes distinguished 
the term 'attitude' from 'opinion', reserving the former for underlying evaluative positions and the latter for verbal statements of those positions. This distinction is plausible when making certain traditional assumptions, but it is not used consistently in the market research we are studying. Moreover, even traditional researchers find it hard to sustain consistently in practice. On the one hand, for example, popular recent definitions of attitude (such as Zanna \& Rempel, 1988) define attitudes as 'evaluative categorizations' (starting to blur the distinction between evaluation and action) and attitudes are anyway typically (although not always) operationalized in research studies in terms of discourse activities ('verbal responses'). On the other hand, research on people's 'opinions' is rarely concerned with verbal statements as such (how they are occasioned, what they are doing); in practice 'public opinion' is treated as an underlying variable much like attitudes are treated in social psychology (see, for example, Curtice \& Jowell, 1996).

Researchers using focus groups, and discussing focus group methodology, sometimes compound this terminological blurring by describing focus groups as concerned with POBAs an acronym that brings together a deliberately fuzzy set of notions: Perspectives, Opinions, Beliefs and Attitudes (see Puchta, 1999). From our DSP perspective, the analytic topic is 'evaluative practices' (assessments in discourse and their various uses), so we are neither committed to the terms 
'attitude' and 'opinion', nor to producing a technical demarcation between them. Our expectation is that there will be a wide variety of uses of evaluations and the available meta-language may capture some better than others.

\section{Focus groups and interaction}

Focus groups derive their results from interaction and are participant centred. This is emphasised in the various books that are available giving guidance on the proper conduct of focus groups (e.g. Krueger, 1998; Morgan, 1997). It is also typically emphasised by the group moderator (the researcher who is present and guides and oversees the group). For example, this extract is taken from the moderator's introductory remarks at the start of a focus group:

It would be nice, (.) ((clears her throat)) all in all, (1.0) if we could have a >so-called< 个group-discussion, if we could really get into a $\uparrow$ dis $\downarrow$ cussion, =and I don't

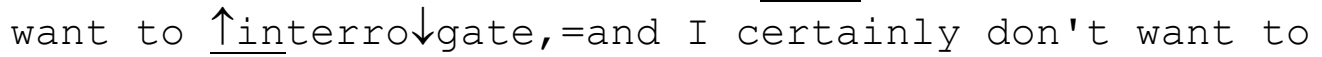
个test $\downarrow_{\text {you }},($.$) and it's not about \uparrow$ know $\downarrow l e d g e$, but about ôpin $\downarrow$ ions, >you just always say, =whatever comes to mind, (.) and there are< no, (.) right or wrong answers.

Note the way the contrast is built between knowledge and opinion, and how participants are encouraged to avoid treating answers as right or wrong.

The relationship between interaction and the 'results' of market focus groups is quite complex. The companies who commission the group (in this case typically concerned with 
extending the line of a particular brand of cigarette) pay for three kinds of output. They may have a representative who watches the interaction from behind a one-way mirror; they will be given a video of the interaction; they will be given a report of the interaction written by the moderator (which typically summarises themes and gives sample quotes of people's 'views'). None of these forms of output takes priority over the others. This means that the moderator is a central part of the data production. He or she can, for example, display the importance of something by showing attention to it or visibly ignoring it. This will be apparent to the client whether through the one-way mirror or on the video, or in what is quoted in the report.

Our general question is how is it that moderators can work with this material, which according to DSP ought to contain evaluations which are variable and rhetorically organized, and can nevertheless manage to pick out attitudes and opinions as decontextualized and freestanding entities in the course of the interaction?

It will help avoid confusion here if we note that there are two notions of interaction in play. On the one hand, there is a traditional social psychological notion of interaction that considers people as owning memories, beliefs and attitudes and considers interaction as an arena in which those things are expressed and communicated. In DSP, on the 
other hand, interaction is treated as a set of occasioned practices where evaluations may be developed and undermined, often built contrastively for ongoing arguments, and where they may sometimes be constituted as 'attitudes' or 'beliefs' tied to individuals.

Note that DSP does not claim that people do not, on occasion, avow personal opinions or construct their talk in the language of freestanding attitudes. What distinguishes DSP from traditional alternatives is how such avowals are understood (broadly, as actions rather than as indexes of underlying dispositions). This means that the empirical phenomena that are most consequential theoretically involve situations where evaluations are rhetorically constructed. These are therefore what will focus on in this paper. And our interest will be in how such phenomena are handled methodologically. That is, how do moderators deal with the rhetorical finessing of argumentation, and in particular how, if at all, do they re-package such formulations into freestanding entities? We will also be concerned with evidence that moderators train participants that freestanding opinions are appropriate to produce in focus groups.

\section{Conversation Analysis of institutions and social research}

In this study we have drawn heavily on the theoretical assumptions and analytic perspective of Conversation Analysis. 
Let us indicate how we have done this and why. One of the main assumptions of Conversation Analysis (henceforth CA) is that contributions to interaction are contextually oriented. Heritage suggests that talk in interaction is both 'context shaped and context renewing' (1984:242). That is, a speaker's contribution is both designed with regard to the local configuration of activity and in particular the immediately preceding actions, and itself inevitably contributes to the framework in terms of which the next action will be understood. This is a dynamic view that considers context not as given, but as an active accomplishment. CA makes a break from conventional approaches of institutional settings that adopt a 'container' model of institutional contexts (Heritage, 1987) and instead emphasises the way participants orient to, and constitute the nature of institutional interaction (Drew and Heritage, 1992).

Recently CA workers have started to apply this perspective to the process of social research itself. For example, Suchman and Jordan (1990) and Schaeffer and Maynard (1996) have studied interactional processes in survey interviews, Antaki and Rapley (1996; Rapley and Antaki, 1996) have studied the administration of a quality of life questionnaire, and Myers and Macnaghten (Myers, 1998; Myers and Macnaghten, 1999) has considered the management of focus group interaction. These studies identify generic organizational problems that appear in research methods such 
as interviews and focus groups, and study the organized solution to them (see also Schegloff, 1990). One way of conceptualizing our current study is as a contribution to this literature on interaction in social research, which has a particular concern with the way participants manage the task of producing opinions out of interaction.

\section{Research questions}

Our research questions are stimulated by the contrast between the claims of DSP about the rhetorical and performative nature of evaluative talk and the presence of a large body of focus group market research that purports to work with and identify individual attitudes and opinions. In particular, we will address the following questions.

- How do moderators deal with interaction between participants in which opinions may be rhetorically developed?

- How do moderators use meta-formulations to encourage freestanding evaluations?

- What procedures are used to strip off the rhetorically embedded nature of evaluations? 


\section{Method}

\section{Analytic materials}

Videotapes of eight focus group tapes run by six different moderators were the analytic basis for this study. The groups were mainly conducted to give advertising people and product managers the possibility to, in their terms, 'experience the experience' of smokers (from behind a one-waymirror). Such groups are routinely video-recorded. Tapes were selected to satisfying the following criteria:

- They used a range of different moderators;

- All the moderators where highly experienced (this was their full time occupation), although they varied in their skill (judged by the head of the market research department);

- Some of the groups covered broad and some narrow topics.

These criteria were chosen to facilitate generalization from the findings.

Each focus group lasted for ninety minutes or more; the number of participants varied from seven to eleven. We transcribed two focus groups from beginning to end, segments of thirty minutes from six focus groups and the opening sequence from every focus group, making altogether more than 
six hours of transcribed talk. Further transcript was made from the video as needed. Out of six moderators in the materials four were male and two were female; this broadly reflects current employment patterns in the area. In all groups, about half of the participants were female. As participants are chosen to reflect the target group of the discussed cigarette brand, only one focus group consisted of middle-aged participants, all the others consisted of 'young' smokers - from the age of eighteen until about twenty-eight.

\section{Transcription and translation}

The focus groups were conducted in German. They were transcribed in German and these transcripts translated into English; a bilingual English speaker checked all translations. The analysis was done on the German original, but for presentation purposes we will work primarily with the English translation. We discussed from case to case, how best to transfer pauses and characteristics of speech production such as emphasized sounds from the German original to the English translation.

All cigarette brands talked about in the groups have been pseudonomized by naming them after capital cities. Participants are named P1, P2 etc.; the moderator is Mod.. 
Standard Jeffersonian transcription conventions have been used throughout (see Ten Have, 1998, for a recent summary). The principle conventions are as follows.

He Underlining indicates stress or emphasis.

(0.8) Numbers in parantheses indicate periods of silence, in tenths of a second. Pauses under 0.5 seconds have not been timed and are shown as (.) .

() Parentheses indicate talk difficult to transcribe. Words inside such parentheses indicate the transcriber's best estimate of what is being said.

[] Left-side brackets indicate where overlapping talk begins; right-side brackets where overlapping talk ends.

$=$ Equal signs indicate a 'latched' relationship without any silence.

- Talk appearing within degree signs is lower in volume relative to surrounding talk.

$>$ 'Greater than' and 'less than' symbols enclose talk that is noticeably faster than the surrounding talk.

, Commas are a 'continuation' marker, indicating that the speaker has not finished; marked by fall-rise or weak rising intonation, as when enunciating lists.

? Question marks signal 'questioning' intonation, irrespective of grammar.

- Periods (full stops) mark falling, stopping intonation ('final contour'), irrespective of grammar, and not necessarily followed by a pause. 
Various features taken from the video (bodily

orientation, writing, non-vocal activities such as opening and holding up cigarette packets) are noted on the transcripts, as they become relevant for the analysis.

\section{Analytic Procedure}

The materials were analysed using techniques from CA and DSP (Drew, 1995; Heritage, 1997; Hutchby and Wooffitt, 1998; Potter, 1996, 1997; Potter \& Edwards, forthcoming; Ten Have, 1998). Rather than attempt to code and categorize the materials, the focus is on the situated nature and action orientation of participants' talk. Participants' own orientations are used as a principle resource for making sense of interaction (if participants treat something as an invitation, say, that is powerful grounds for the analyst treating it in this way). In this case, we are particularly concerned with the orientations displayed by the moderators when participants display evaluations in freestanding or rhetorically embedded ways. Analysis of this kind is at least partly a craft skill and therefore not easy to turn into a specific recipe. However, carefully transcribed examples of the original materials are presented along side the interpretations to allow readers and reviewers to judge the adequacy of claims. 
In the analysis we have mainly chosen to present one instance of each of the phenomena we are concerned with. This is a compromise between journal space and reader patience, on the one hand, and allowing the reader the option to assess our analysis of a range of examples, on the other (further examples and analyses are available in Puchta, 1999). Our analysis is concerned with identifying a normative pattern rather than a general statistical association, so our analysis of potential deviant cases is particular important for supporting the adequacy of our claims.

\section{Analysis}

\section{Rhetorical construction and moderator recipiency}

Let us start with a relatively coarse grained observation about moderator recipiency. The moderators in our sample display attention (that is, visibly attend) to freestanding opinion formulations and display disattention to (explicitly) rhetorically embedded formulations. In Figure one the talk is schematically summarized rather than directly transcribed to highlight this pattern of interaction. The arrows indicate to whom speakers address their contributions (shown by posture and gaze) .

\section{Insert Figure One about here.}


Asked to describe a cigarette's taste the participants P1, P3, P4, P5 and P6 initially report assessments directly to the moderators (there are two moderators in this focus group) and the moderators take notes. However, participants P3, P4 and P5 then address comments to each other (see circles $V$ and VI). The point of interest here is that the moderators do not write down these comments. In VII P2 redirects interaction to the moderator with his comment:

Well I'll stick to it.

This not only receives an explicit receipt from the moderator ('Hm $\mathrm{mm}, '$ ), but is also written down. The contrast here, then, is in the moderators differential attention to contextually and rhetorically formulated contributions such as 'No, I don't think so' (see circle V) and freestanding individual opinions such as 'Well I'll stick to it' (circle VII) .

This example is a useful start-point as it illustrates the kind of phenomena of interest. However, what is going on is often more subtle than this. In the following 3 sections we will look at techniques that moderators use to head off interaction between participants with its associated rhetorical construction of evaluations and to formulate freestanding opinion packages from rhetorically organized talk. 


\section{Displaying inconsequentiality}

One of the most straightforward techniques for displaying the inconsequentiality of rhetorically embedded evaluations is to ignore them. This is seen in the interaction patterns above. Let us consider an example in detail.

The following extract comes from a focus group where the participants are discussing the name for a new cigarette brand. 'Cape Blue Ultra' is the proposed name for a planned light line extender (lower tar version) of the stronger 'mother brand' 'Cape'; the Cape Blue Ultra packet is blue, the Cape packet is red.

(2) Source: Blue17,919; file: diagrala; video: 27:11

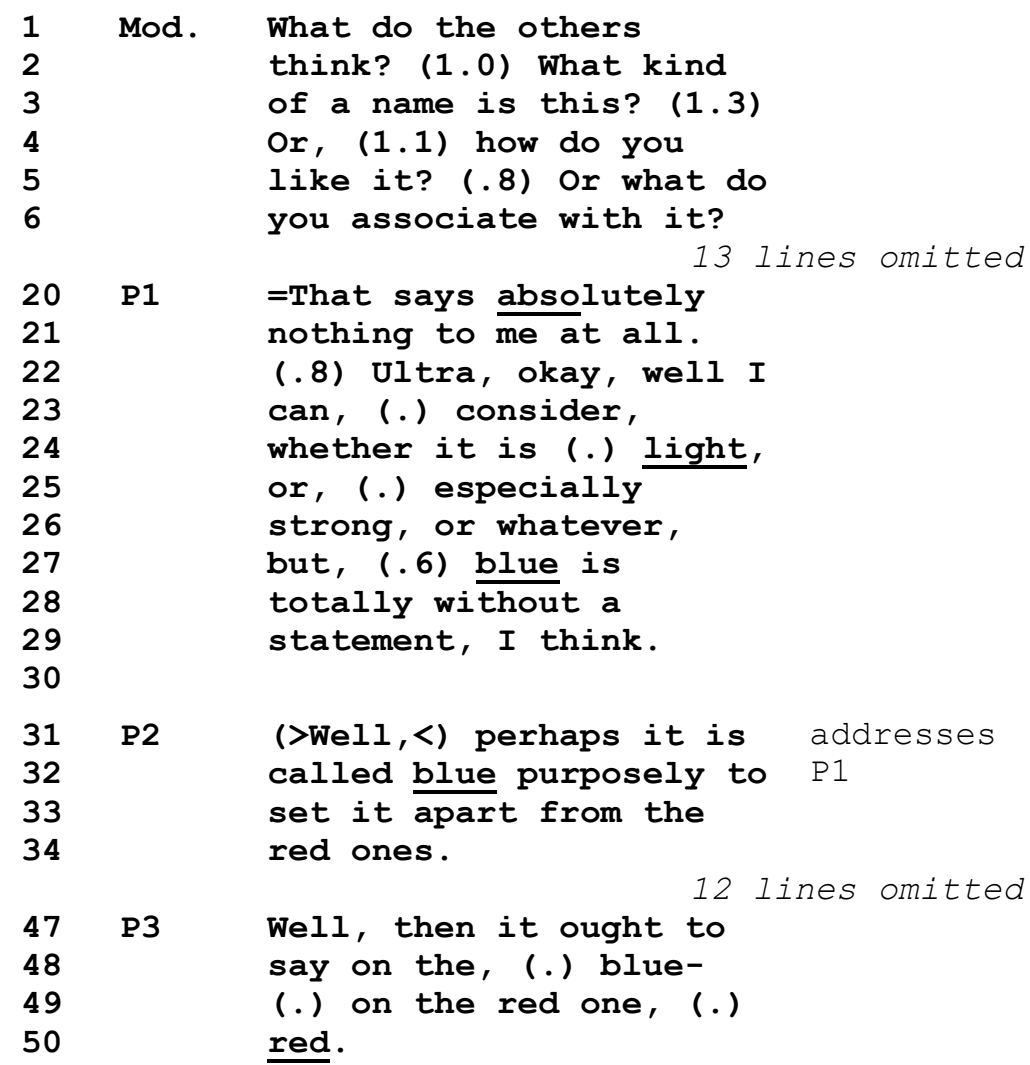

Was meinen die andern? (1.0) Was ist das fürn Name? (1.3) Oder, (1.1) wie findet Ihr den? (.8) Oder was fällt Euch dazu ein?

=da kann ich mir überhaupt nichts mehr drunter vorstellen. (.8) ultra, okay, da kann ich, (.) mir noch überlegen, ob das nun (.) leicht, oder, (.) besonders schwer is, oder sonst was, aber, (.6) blue hat irgendwie überhaupt keine Aussage, find ich.

$(>\mathrm{Ja},<)$ vielleicht heisst die blue extra, um die von den roten abzusetzen.

Ja, dann müsste ja bei der, (.) blau- (.) bei der roten, (.) müsste red draufstehen. 


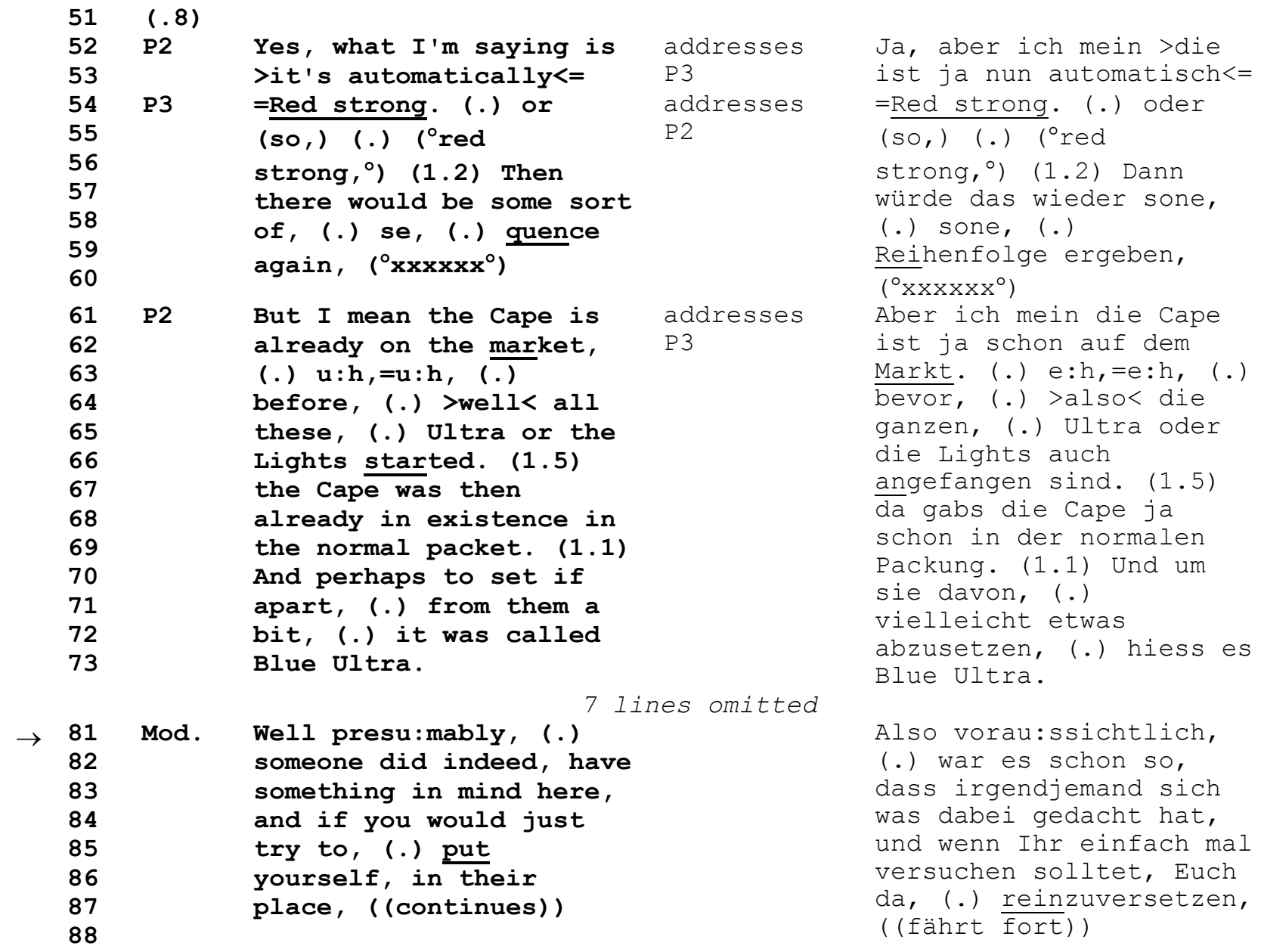

Without going to far into the complexities of this extract, what we wish to concentrate on are the arguments put forward in particular by P1 against the usefulness of the name ('blue is totally without a statement, I think.'; lines 27-9) and P2's defence of the brand name: ' $(>$ Well, $<$ ) perhaps it is called blue purposely to set it apart from the red ones.' (lines 31-4). P2 thus offers an argument for calling the brand 'Cape Blue Ultra'. When $\mathrm{P} 3$ rejects this by pointing out, that, following his argument, the cape in the red packet should be called 'the red Cape', P2 claims, that this argument is a theoretical one, as the original Cape was introduced a long time before light cigarette brands have been on the 
market. The moderator then asks, or, more precisely, gives a 'directive as a question substitute' (Heritage and Roth, $1995):$

Well presu:mably, (.) someone did indeed, have something in mind here, and if you would just try to, (.) put yourself, in their place, ((continues)) (lines 81-7).

Note the way that the moderator avoids acknowledging P2's argument. In emphasising that someone did have something in mind in giving the line extender the name 'Cape Blue Ultra' she implies, that up to then nobody in the group 'had something in mind' and urges the group members to put themselves 'in their place'. Although the moderator has tolerated talk between participants, she displays it as inconsequential.

The general point, then, is the way that the moderator encourages participants to produce freestanding opinions by ignoring opinions that are produced in discussion between participants. This displayed disattention will be available to the observer using the one-way mirror, of course, as it is on the video.

\section{Meta requests for freestanding opinion talk}

Sometimes moderators 'go meta'. That is, they provide explicit formulations of the kind of contributions that are welcome (cf. Simons, 1989). These formulations do not 
explicitly ask for freestanding opinions; however, they provide examples where this feature is apparent.

Consider the following extract. It revolves around a socalled projective question concerning the features of a typical smoker of the brand London.

(3) Source: London,596; file: eviden3; video: 33:04

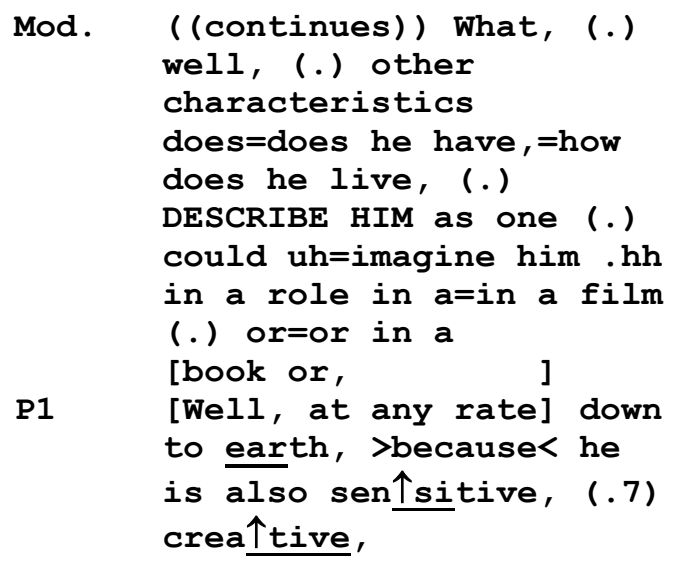

(1.1)

Mod

(1.6)

P2

P1

P3

$\mathrm{Hm} \mathrm{mm}$,

Hedo[nist, ] [Educated,] yes,

P2 Likes eating out,

P1 Yes,

P3 $(\operatorname{xx} \times x \times)=$

Mod. =Yes, EVERYBODY IS

P1 [Yes, ] =

Mod. =describe his own.=now [don't lets talk]

P1

[Educated, ] (.)

and well also a hedonist, that's it [ (now) ]

Mod. [Hedo-,] okay, yes, that's already pretty vivid ((continues)) ((fährt fort)) Was, (.) so, (.) hat=hat er noch für Eigenschaften, =wie lebt er so, (.)

BESCHREIBEN SIE ihn ma so wie man sich den.hh inner Rolle inm=inm Kino (.) eh=vorstellen könnte (.) (oder=oder im [Buch oder, )]

[Also halt auf jeden Fall ] bodenständig, >weil halt< auch sen $\uparrow$ sibel, (.7) krea个tiv,

$\mathrm{Hm} \mathrm{mm}$,

Genuss [mensch, ]

addresses [Gebildet, ] ja,

P2

addresses

P2

addresses

P2

addresses P2

addresses P 4
$\mathrm{Ja}$,

Geht gerne essen, Ja,

$(x \times x x x)=$

$=\mathrm{Ja}$, JEDER DARF SEINEN [EIGENEN] $=$

$[\mathrm{Ja}, \quad]=$

=beschreiben.=jetzt [reden wir mal nicht] [Gebildet, (.) und halt auch nen Genussmensch, das wars dann halt [ (auch) ] [Genuss-, ] okay, ja, das ist ja schon ma ganz plastisch, ( (fährt fort)) 
The notable thing here is that when P1, P2 and P3 begin a joint description of the typical smoker of London cigarettes, the moderator shouts emphatically:

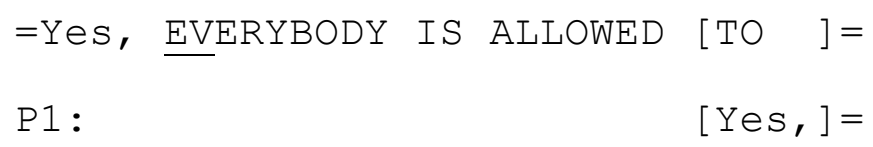
talk at once' (the incompleteness here might lessen the effect of telling the participants off). The moderator goes meta in the sense that he explicitly offers a rule on how to provide contributions: everybody has the right to describe his/her 'own typical smoker'. It is notable that after this turn the participants return their focus to the moderator, addressing their contributions to him. Thus P1 elaborates on her own projective smoker, and produces it as a freestanding description addressed to the moderator:

[Educated,] (.) and well also a hedonist, that's it [ (now)] (lines 34-7).

The moderator acknowledges and confirms the description ('[Hedo-,] okay, yes, that's already pretty vivid'; lines 3840)

Note the way the detail of the interaction is in line with our general account. Pl's description in 34-7 is more or less a combination of her own and P2's earlier contributions 
(P2 has provided 'He[donist,]' (line 19) and P1 '[Educated,] yes,' (line 20)). When the three participants produce contributions linked by agreement tokens ('yes') these are queried by the moderator. However, when a participant formulates very similar contributions as a freestanding opinion, and when it is addressed to the moderator, the opinion is not only accepted but also praised. The general observation here is that the moderator's intervention with a meta observation about the conduct of the participants leads to the production of a freestanding opinion package.

So far we have considered how the moderators deal with rhetorically oriented opinion production by ignoring it or making explicit injunctions against it. We will now consider another approach, which is for moderators to 'strip off' the rhetorical elements and thereby formulate freestanding opinion packages .

\section{Stripping off the rhetorical context}

Let us consider an example of stripping off rhetorical context. This is an exercise where the moderator asks which brands the participants would place near the light cigarette brand Stansted $^{1}$ in a hypothetical shelf.

(4) Source: Hensted7,932; file: echo53; video: 29:30;

1 Mod. ((continues)) imagine, =>you go 


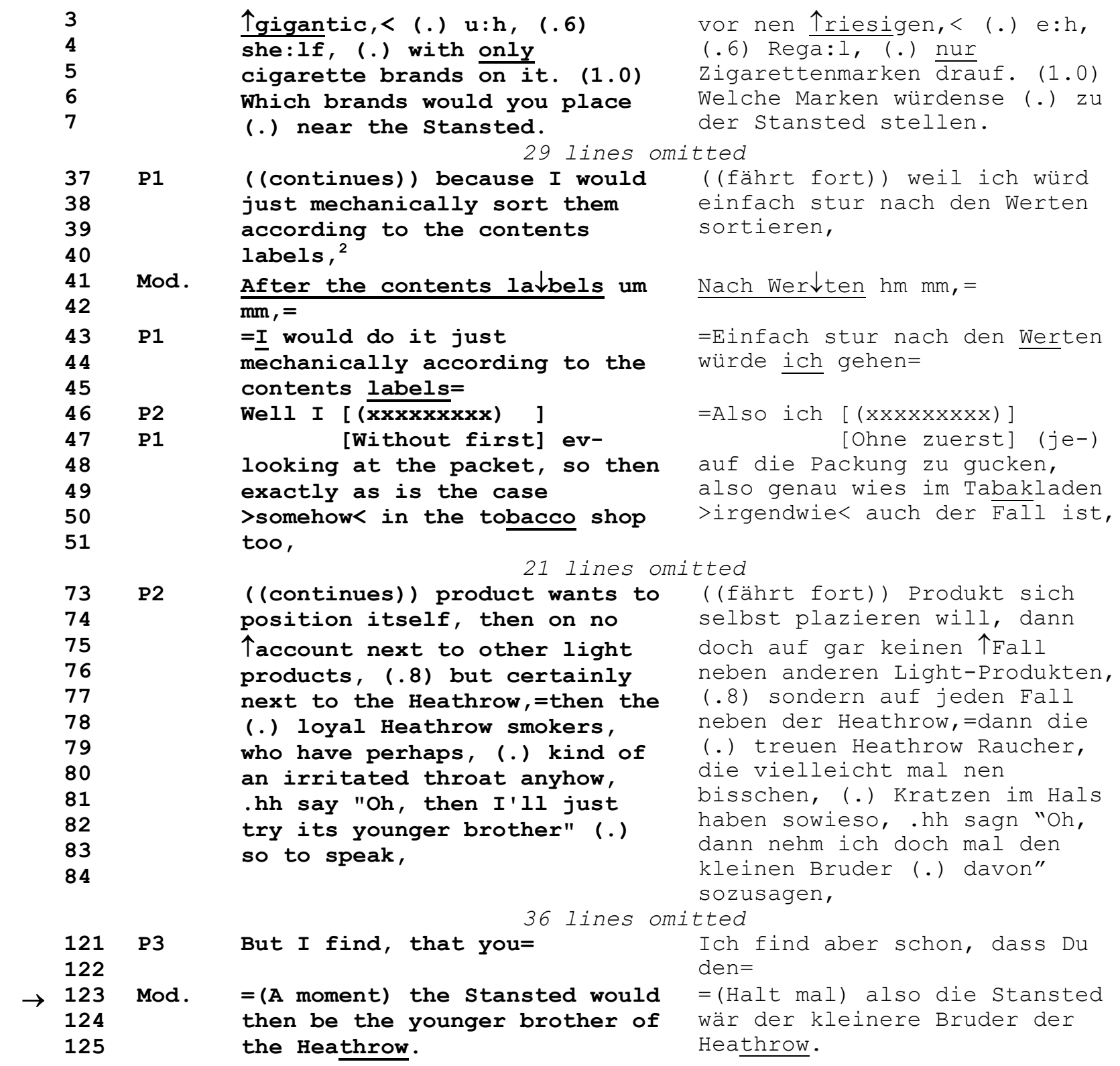

Near the start of the sequence P1 stresses he would categorize brands 'mechanically' according to 'labels' (lines 37-40). During $\mathrm{PI}^{\prime}$ s turn the moderator orients his attention to other participants and P2 starts to come in. However, P1 continues displaying his opinion. P2 then presents his opinion in using an extreme case formulation (Pomerantz, 1986; Edwards, in press): 
on no 个account next to other light products, (lines 74$6)$.

He constructs his argument as a counter-argument to P1 and stresses that the very light stansted should be positioned next to the less light Heathrow, so that Heathrow smokers with an 'irritated throat' (line 80) might say: '"Oh, then I'll just try its younger brother"' (lines 81-2).

Now comes the phenomenon of interest. At the end of $\mathrm{P}^{\prime}$ 's long turn, a third participant (P3) tries to gain the floor, but is interrupted by the moderator:

$=(A$ moment $)$ the stansted would then be the younger brother of the Heathrow. (lines 123-5)

The moderator formulates an element of P2's talk which has been used to undermine P1's argument (see Heritage, 1985). What we see, then, is that the moderator picks out an argument used to support a particular position and presents it as a freestanding thing. The general point here is that when participants produce evaluative talk, which develops explicit rhetorical contrasts, these can be removed to leave the evaluations as freestanding entities tied to individuals.

In our corpus there is, however, evidence that there is a conversational environment in which the production of nonfreestanding opinion displays is tolerated, that is, attended to, and formulated as focus group relevant. In our final 
section we will attend to such deviant cases and consider their implications for our general claims.

\section{Deviant cases}

Up to now we have claimed that moderators in market research focus groups display a preference for individual opinions in the form of freestanding packages. They systematically ignore rhetorically developed opinions, or explicitly offer 'rules' against their use, or they formulate such opinions with their rhetorical elements stripped off. However, there are certain occasions where agreement tokens are tolerated as rhetorically formulated contributions. These are particularly interesting as potential cases which might raise problems for the sorts of pattern we have identified, or which allow us to refine our claims. In this section we will look more closely at the environment in which such sequences are embedded.

The following extract revolves around discussion of the 'typical smoker' of Cape Blue Ultras. The moderator is following up on a participant's description, asking her whether the 'typical smoker' is a man or a woman.

(5) Source: Blue17,334; file: eviden7; video: 12:13 


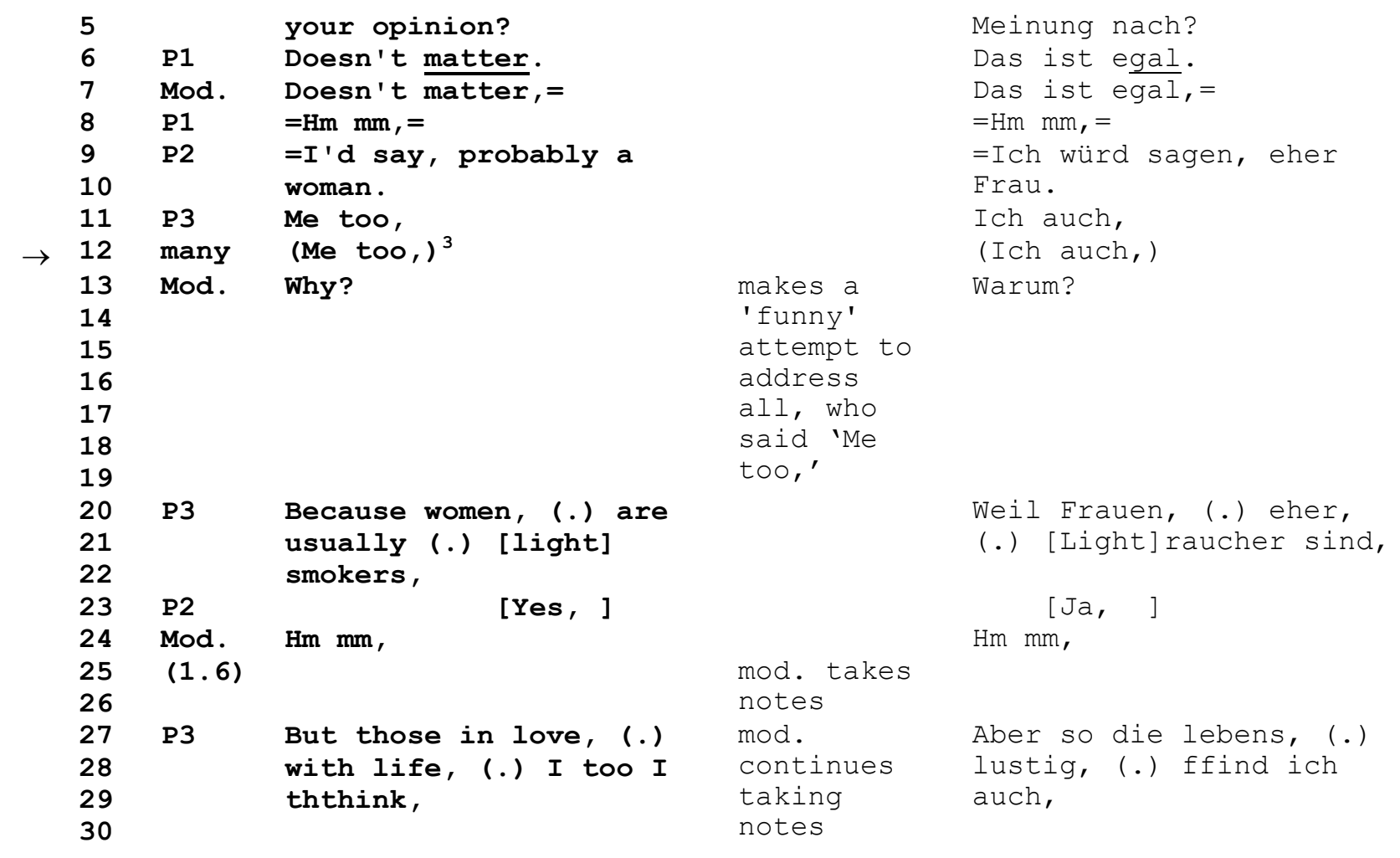

In response to the moderator's question at the start of the extract $\mathrm{P} 1$ says the gender of the imaginary smoker does not matter. This is immediately contradicted by P2: '=I'd say, probably a woman.' (lines 9-10). P3 supports P2 ('Me too,'; line 11) and several other participants join in and signal their approval. The moderator makes a hearably and visibly humorous attempt to address this group of participants and asks for their reason for the judgement (line 13). What is interesting here, is the way that the 'me too-advocates' are treated as a single entity with a collective view. Unlike other interactions, they are not asked to describe their individual judgements 'in their own words'.

How can we account for this deviant case? We suggest that it marks out a distinction between qualitative opinions 
and categorical judgements. Think of the difference between the question 'do you smoke Marlboro?' which can be answered with a yes or no, and 'what is it about Marlboro that you like?' that would require you to specify some qualities or attributes. In the former case, agreement token are readily interpretable as placing participants in a category; while in the latter case they leave the association of particular participants with individual qualities opaque or ambiguous.

Let us take a further case to explore this. While Extract 5 involved a categorical judgement about gender, the moderator in the next extract asks for a numerical judgement:

how long does one need when one tries a new brand, until one, (.6) <comes to a reasonably satisfactory conclusion about it, $>$ (lines 1-5)

Note the way the moderator again accepts again agreementtokens (line 29).

(6) Source: Blue19,773; file: eviden6; video: 46:16

$\begin{array}{ll}1 & \text { Mod } \\ 2 & \\ 3 & \\ 4 & \\ 5 & \\ & \\ 17 & \text { P1 } \\ 18 & \\ 19 & \\ 20 & \\ 21 & \\ 22 & \\ 23 & \\ 24 & \\ 25 & \\ 26 & \\ 27 & \\ 28 & \end{array}$

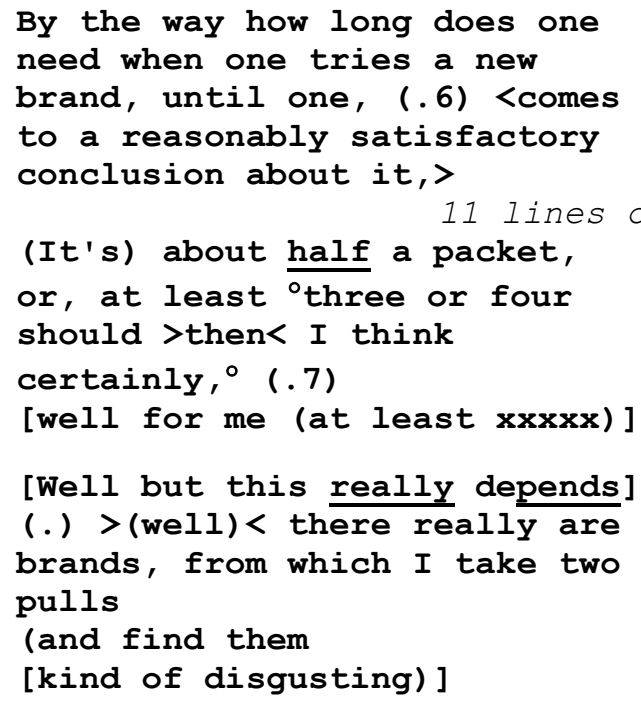

Wie lange braucht man eigentlich wenn man sone neue Marke probiert, bis man so, (.6) <einigermassen für sich nen stimmiges Urteil hat, > omitted

(Des is) sone halbe Packung, oder, zumindest ${ }^{\circ}$ drei vier Stück sollten >dann< glaub ich schon, ${ }^{\circ}(.7)$

[also brauch ich (zumindest $\mathrm{xxxxx)]}$

[Also das kommt echt darauf an ] (.) $>($ also $)<$ es gibt echt Marken, da rauch ich zwei Züge

(und find sie

[eigentlich widerlich)] 


\begin{tabular}{|c|c|c|c|}
\hline 29 & many & {$\left[\left(\right.\right.$ Yes $^{4}$} & {$[\mathrm{Ja}$,} \\
\hline 30 & P1 & (Also.) (.8) but with this one & $\begin{array}{l}\text { (Auch.) (.8) aber bei dieser } \\
\text { wïsst ichs jetzt nicht }\end{array}$ \\
\hline 32 & P2 & No, 5 & Nee, \\
\hline $\begin{array}{l}33 \\
34 \\
35\end{array}$ & $\begin{array}{l}+ \\
\text { some } \\
(2.3)\end{array}$ & & \\
\hline $\begin{array}{l}36 \\
37\end{array}$ & Mod. & $\begin{array}{l}\text { And what would you assume } \\
\text { ((continues)) }\end{array}$ & $\begin{array}{l}\text { Und was würdest Du vermuten } \\
\text { ((fährt fort)) }\end{array}$ \\
\hline
\end{tabular}

Let us highlight two features of this sequence. First, the question is unusual in asking for a number of some kind ('how long') rather than for a qualitative opinion. Second, the answers are organized contrastively (three or four cigarettes vs. two pulls vs. don't know). Although this is not quite as simple as the previous case, the continuum is chunked into three categories. It is these categorical claims that receive the unqualified agreements and disagreements.

The general point, then, is that there is an environment in these market research focus groups where agreement and disagreement tokens are treated as acceptable. This environment is one where the participants are offering categorical judgements, or judgements on a numerical continuum, rather than qualitative opinions.

\section{Discussion}

Let us summarise the main points of our analysis before discussing some more general issues to do with focus group practice and the discursive social psychology of attitudes. We 
have tried to show the way freestanding individual opinion packages are produced in focus groups. That is, although evaluative talk is recurrently produced in the form of rhetorical contrasts and agreement/disagreement tokens, the moderator deals with this kind of talk in three particular ways .

- First, and most simply, it is ignored (Sections 1 \& 2).

- Second, various occasioned meta rules or injunctions are developed to support the production of freestanding opinion packages (Section 3).

- Third, when moderators formulate opinion packages out of sequences where participants produce them rhetorically and contrastively, these rhetorical elements are stripped off to leave freestanding opinion packages (Section 4).

Finally, we considered deviant cases. The only examples that fell outside the three management techniques where those where participants were offering categorical judgements.

We have concentrated here specifically on the individuation of evaluative talk into personal opinion packages. However, elsewhere we have considered the way in which moderators generate 'opinion talk' rather than 'factual talk', as well as the use of 'repeat receipts' as a common device for stripping off rhetorical orientations (Puchta, 1999; Puchta \& Potter, forthcoming). 
With respect to the practice of focus groups, the production of individual and freestanding opinions is typically what is required. For example, one of the most popular manuals on the conduct and analysis of focus groups describes three different models of report writing:

The first style of presentation consists of the question or idea and is followed by all participant comments (the raw data model). The second style is a summary description followed by illustrative quotes (the description model). The third style is a summary description with illustrative quotes followed by an interpretation (the interpretative model). (Krueger, 1994:167, emphasis added)

Krueger gives examples of 'illustrative quotes' for a focus group on the topic what parents look for in youth organizations:

The person in charge must be a good influence because children idolize their leaders.

Leaders are the most important thing in a youth organization. I don't want a crank for a leader.

I want a adult who is patient and kind to work with my kids. (1994:167)

Such quotes are in the form of what we have called freestanding opinion packages. For example, they are similar to the participant's utterance in Extract 1 that was considered worth writing down by the moderator:

>Well I'll stick to it.< I think it's a bit aromatic. ${ }^{6}$

What we have observed in our materials, then, is in line with the 'good practice' formulated by Krueger. 
We do not wish to criticise this practice here; in some ways it seems to be well suited to the goals of market research. We can speculate that such freestanding opinion packages are relatively easy to understand for the audience watching the group, and relatively easy to draw market-related conclusions from. Furthermore, they provide relatively straightforward raw material for the moderator to write up. Colourful descriptive evaluations can be tied to individual participants and the scope of agreement/disagreement tokens does not have to be determined. This may provide a simpler basis on which to make practical recommendations.

What we have revealed are the detailed interactional procedures through which these opinion packages are produced. It may be that an alternative moderating and analytic practice that highlights rather than obscures the rhetorical organization of evaluations would be a basis for different or even improved recommendations. However, we have no evidence either way on this issue. Moreover, it would be a particularly difficult issue to resolve: for what neutral method would be used to assess the impact of these different methodological practices? Luckily this is, anyway, not our primary concern in this paper.

Our broader concern is with the nature of opinions and attitudes and their conceptualization in social psychology. We started with the puzzle that traditional attitude research 
tends to discover enduring underlying attitudes without being troubled by the kinds of variability and rhetorical

organization highlighted in DSP. Our proposed methodological answer to this puzzle is that attitude measurement procedures have features that obscure these features. The example of market research focus groups illustrates one way in which this can happen.

This evidence does not directly undermine traditional conceptualizations of attitudes in favour of the DSP approach to evaluative practices. Nor does it criticise recent developments in attitude theory. That is not its point. Rather it counters the argument that the DSP approach cannot be true because various kinds of traditional attitude research work. It illustrates one way in which such work may miss the phenomena highlighted by DSP. And it complements arguments about the way quantitative attitude measures may miss such phenomena for different reasons (Billig, et al., 1988; Potter, 1998; Potter and Wetherell, 1987).

To end with we would like to offer two more general points. First, it is undoubtedly the case that the reconstruction of rhetorically embedded evaluations into freestanding opinion packages is not restricted to focus groups. Our guess is that it is a feature of a range of everyday and institutional practices. One of the aims of a discursive social psychology of evaluation will be to study 
these practices and highlight both their generic and specific features

Second, and more speculatively, we would like to highlight a link to more sociological and historical conceptualizations of the nature of social science and its objects. One of the arguments of the philosopher and discourse analyst Michel Foucault (1972) is that the objects of social science study are constituted out of its discourse practices. Much work within the Foucaultian research tradition has taken an expansive historical perspective (e.g. Danziger, 1990; Rose, 1989). In this case we have shown how the practices of focus group moderation can constitute freestanding opinion packages as social science objects. 


\section{References}

Antaki, C. (1994). Explaining and Arguing: The Social

Organization of Accounts. London: Sage.

Antaki, C. \& Rapley, M. (1996). 'Quality of life' talk: The liberal paradox of psychological testing. Discourse and Society, 7, 293-316.

Atkinson, J.M. \& Heritage, J. (eds.)(1984). Structures of Social Action: Studies in Conversation Analysis. Cambridge: Cambridge University Press.

Billig, M. (1985). Prejudice, categorization and particularization: From a perceptual to a rhetorical approach. European Journal of Social Psychology, 15, 79103.

Billig, M. (1988). Rhetorical and historical aspects of attitudes: The case of the British monarchy. Philosophical Psychology, 1, 83-103.

Billig, M. (1989). The argumentative nature of holding strong views: A case study. European Journal of Social Psychology, 19, 203-223.

Billig, M. (1991). Ideologies and Beliefs. London: Sage. Billig, M. (1992). Talking of the Royal Family. London: Routledge.

Billig, M. (1996). Arguing and Thinking: A Rhetorical Approach to Social Psychology (2nd edn.). Cambridge: Cambridge University Press. 
Billig, M., Condor, S., Edwards, D., Gane, M., Middleton, D. \& Radley, A. (1988). Ideological Dilemmas: A Social Psychology of Everyday Thinking. London: Sage. Burningham, K. (1995). Attitudes, accounts and impact assessment. The Sociological Review, 43, 100-122.

Curtice, J. \& Jowell, R. (1996). Pubic opinion polls. In A. Kuper \& J. Kuper (Eds). The Social Science Encyclopedia (2 $2^{\text {nd }}$ E.). London: Routledge.

Danziger, K. (1990). Constructing the subject: Historical origins of psychological research. Cambridge: Cambridge University Press.

Drew, P. (1995). Conversation analysis: The sequential analysis of intersubjectivity in conversation. In J. Smith, R. Harré and L. van Langenhove (eds.), Rethinking Methods in Psychology. London: Sage.

Drew, P. \& Heritage, J. (1992). Talk at Work: Interaction in Institutional settings. Cambridge: Cambridge University Press.

Eagly, A.H. \& Chaiken, S. (1993). The Psychology of Attitudes. New York: Harcourt Brace Jovanovich. Edwards, D. (1991). Categories are for talking: On the cognitive and discursive bases of categorization. Theory and Psychology, 1 (4), 515-542.

Edwards, D. (1997). Discourse and Cognition. London and Beverly Hills, CA: Sage. 
Edwards, D. (in press) Extreme case formulations: Softeners, investments and irony, Research on Language and Social Interaction.

Edwards, D. \& Potter, J. (1992). Discursive Psychology. London: Sage.

Edwards, D. \& Potter, J. (1993). Language and causation: A discursive action model of description and attribution. Psychological Review, 100, 23-41.

Foucault, M. (1972). The archaeology of knowledge. London: Tavistock.

Heritage, J. (1984). Garfinkel and Ethnomethodology. Cambridge: Polity

Heritage, J. (1985). Analyzing news interviews: Aspects of the production of talk for an overhearing audience. In T.A. van Dijk (ed.), Handbook of Discourse Analysis (Volume 3). London: Academic Press, 95-117.

Heritage, J. (1987). Ethnomethodology, in A. Giddens \& J. Turner (eds.), Social Theory Today. Cambridge: Polity, $224-272$.

Heritage, J. (1997). Conversation analysis and institutional talk: Analysing data. In D. Silverman (ed.), Qualitative Research: Theory, Method and Practice. London: Sage, 161182.

Heritage, J. and Roth, A.L. (1995). Grammar and institution: Questions and questioning in the broadcast news interview. Research on Language and Social Interaction, $28(1), 1-60$ 
Hutchby, I. \& Wooffitt, R. (1998). Conversation Analysis: Principles, Practices and Applications. Cambridge: Polity

Krueger, R.A. (1994). Focus Groups: A Practical Guide for Applied Research (2nd edn.). Thousand Oaks, CA: Sage. Krueger, R.A. (1998). Moderating Focus Groups (Focus Group Kit, vol.4). Thousand Oaks, California: Sage. Litton, I. \& Potter, J. (1985). Social representations in the ordinary explanation of a 'riot'. European Journal of Social Psychology, 15, 371-88.

Manstead, A.S.R. (1995) Attitude theory and research. In Manstead, A.S.R. \& Hewstone, M. (Eds). The Blackwell Encyclopedia of Social Psychology. Oxford: Blackwell. Morgan, D.L. (1997). Focus Groups as Qualitative Research (2nd edn.). Thousand Oaks, California: Sage.

Myers, G. (1998). Displaying opinions: Topics and disagreement in focus groups. Language in Society, 27(1), 85-111.

Myers, G. \& Macnaghten, P. (1999). Can focus groups be analysed as talk? In R.S. Barbour \& J. Kitzinger (eds.), Developing Focus Group Research. London: Sage, 173-185. Pomerantz, A.M. (1986). Extreme case formulations: A way of legitimizing claims. Human Studies, 9, 219-229. Potter, J. (1996) Discourse analysis and constructionist approaches: Theoretical background. In J.R.E. Richardson (ed.), Handbook of Qualitative Research Methods for Psychology and the Social Sciences. Leicester: British Psychological Society, 125-140. 
Potter, J. (1997). Discourse analysis as a way of analysing naturally occurring talk. In D. Silverman (ed.), Qualitative Research: Theory, Method and Practice. London: Sage, 144-160.

Potter, J. (1998). Discursive social psychology: From attitudes to evaluative practices. European Review of Social Psychology, Volume 9, edited by W. Stroebe \& M. Hewstone.

Potter, J. \& Edwards, D. (forthcoming). Discursive social psychology. In P. Robinson (Ed.). The Handbook of Language and Social Psychology (2 $2^{\text {nd }}$ Ed.). London: Wiley. Potter, J. \& Wetherell, M. (1987). Discourse and Social Psychology: Beyond Attitudes and Behaviour. London: Sage. Potter, J. \& Wetherell, M. (1988). Accomplishing attitudes: Fact and evaluation in racist discourse. Text, 8(1-2), $51-68$

Puchta, C. (1999). Beyond spontaneity: The accomplishment of focus group talk. PhD thesis, Loughborough University. Puchta, C. \& Potter, J. (1999). Asking elaborate questions: Focus groups and the management of spontaneity. Journal of Sociolinguistics, 3, 314-35.

Puchta, C. \& Potter, J. (forthcoming). Focus Group Practice: Moderating Interaction in Market Research Focus Groups. London: Sage.

Rapley, M. \& Antaki, C. (1996). A conversation analysis of the 'acquiescence' of people with learning difficulties. 
Journal of Community and Applied Social Psychology, 6, $207-227$.

Rose, N. (1989). Governing the soul. London: Routledge.

Sacks, H. (1963). Sociological description. Berkeley Journal of Sociology, 8, 1-16.

Sacks, H. (1992). Lectures on Conversation, Volumes 1+2, edited by G. Jefferson. Oxford: Basil Blackwell.

Schaeffer, N.C. \& Maynard, D.W. (1996). From paradigm to prototype and back again: Interactive aspects of cognitive processing in standardized survey interviews. In N. Schwarz \& S. Sudman (eds.), Answering Questions: Methodology for Determining Cognitive and Communicative Processes in Survey Research. San Francisco, CA: JosseyBass, 65-88.

Schegloff, E.A. (1990). Comment on Suchman and Jordan. American Statistical Association, 85(409), 248,249.

Simons, H. (1989). 'Going meta' in political confrontations. In B. Gronbeck (ed.), Spheres of Argument. Annandale, VA: SCA.

Suchman, L. \& Jordan, B. (1990). Interactional troubles in face-to-face survey interviews. Journal of the American Statistical Association, 85(409), 232-241.

ten Have, P. (1998). Doing Conversation Analysis: A Practical Guide. London: Sage.

Verkuyten, M. (1998). Attitudes in public discourse: Speaker's own orientations. Journal of Language and Social Psychology, 17, 302-22. 
Wetherell, M. \& Potter, J. (1992). Mapping the Language of Racism: Discourse and the Legitimation of Exploitation. London: Harvester Wheatsheaf .

Wetherell, M., Stiven, H. and Potter, J. (1987) Unequal egalitarianism: A preliminary study of discourses concerning gender and employment opportunities. British Journal of Social Psychology, 26, 59-71.

Zanna, M.P. and Rempel, J.K. (1988) Attitudes: A new look at an old concept. In Bar-Tal, D. \& Kruglanski, A.W. (Eds) The Social Psychology of Knowledge (pp. 315-34). Cambridge: Cambridge University Press.

\footnotetext{
1 The pseudonyms of two brands are airports to show that they belong to the same 'family'.

2 The participant refers to the nicotine and tar level of cigarettes as declared on the respective packet.

3 This defies transcription as the participants say one after another and simultaneously 'Me too,'. This defies transcription as the participants say one after another and simultaneously 'Yes,'. This defies transcription as the participants say one after another and simultaneously 'No,'. Utterance is in contrast to Figure 1 not schematically summarized, but directly transcribed.
} 